\title{
The Influence Of Protean Career Attitude On Proactive Work Behavior With Passion For Work And Career Self Management As Mediator Milennial Employees Dki Jakarta Provincial Government
}

\author{
Ade Maya Saraswati \\ Universitas Negeri Jakarta \\ Email: ademayahasan@gmail.com \\ Dedi Purwana \\ Universitas Negeri Jakarta \\ Email: dpurwana@unj.ac.id \\ Henry Eryanto \\ Universitas Negeri Jakarta \\ Email: henry@feunj.ac.id
}

\begin{abstract}
The purpose of this study is to determine and analyze the influence of protean career attitude toward proactive work behavior with passion for work and career self management as a mediators. The sample determination uses purposive sampling technique. There are 389 respondents used as the samples in this research and are analyzed using Structural Equation Model (SEM). The result from this research is that protean career attitude has a significant positive effect to proactive work behavior. Protean career attitude has a significant positive effect to the passion for work. Passion for work has a significant positive effect to proactive work behavior. Protean career attitude has a significant positive effect to career self management. Career self management has a significant positive effect to proactive work behavior. Protean career attitude has a significant effect to proactive work behavior through passion for work. Protean career attitude has a significant effect to proactive work behavior through career self management.
\end{abstract}

Keywords: Proactive Work Behavior, Passion For Work, Protean Career Attitude Career Self Management.

Received: 19 January 2020 ;

Accepted: 2 March 2020 ;

Publish; June 2020.

\section{How to Cite:}

Saraswati, A.M., Purwana, D., \& Eryanto, H. (2020). The Influence Of Protean Career Attitude On Proactive Work Behavior With Passion For Work And Career Self Management As Mediator Milennial Employees Dki Jakarta Provincial Government. International Journal of Human Capital Management, 4 (1), 74-81. https://doi.org/10.21009/IJHCM.04.01.06 


\section{INTRODUCTION}

From time to time, generation gap will always develop. In the work environment, generation gap becomes an object that will always exist in the development of human resources management. According to Noe (2016), there are five generations of the workforce in an organization based on year of birth. The first generation is traditionalist or silent generation who was born in 1925-1945. The second is baby boomerss generation who was born in 1946-1964. The next generation is X generation who was born in 1965-1979, next is millennial generation who was born in 1980-1999. The last is Z generation with the year of birth between 2000-2020.

Twenge (2010) stated that millennial generation was born in the era of information technology and education is developing, so that they have very different characters compared to the previous generations. Gallup (2016) stated that millennials in the world of work have different characters compared to the previous generations, like millennials work is not just to get a salary but also to achieve their dreams, millennials don't prioritize work satisfaction too much, but what they want more is self development in their work, millenials don't like leaders who are bossy and likes watching them, millennials don't like annual assessment, millenials don't think to fix their weaknesses, millenials think more about developing their strengths.

Based on the data from Regional Staffing Agency of DKI Jakarta, the total number of millennial generation employees in the government of DKI Jakarta Province in January 2019 reached 14.756 employees or 22 percents from the total of employees in DKI Jakarta Province with the total of 65.952 employees. And it is predicted that the total number of millennial employees will continue to grow, because $30 \%$ of the employees of DKI Jakarta Province are baby boomerss generations with the age above 55 years old who will soon retire.

According to Lynch (2008) X generation and baby boomerss are not easy to employ millennial generations who have different meaning and hopes for career compared to the previous generations. So it is with millennial generations who are required to have a work attachment to things that are not in accordance with the believed values, like the existence of authority from stagnant leader and work. Crant (2000) argued that those changes caused the institution to be under pressure in order to adjust with dynamic circumstances. The work becomes more dynamic, making proactive behavior to be regarded as more critical determintant than the success of an organization. Maden (2015) stated that institution expected the employees to exceed the work limit. Parker \& Collins (2010) revealed that proactive behavior was very important in a decentralized workplace this time, which competition is greater and pressure is increasing to innovate. However, based on the pre survey results which have been propagated to 30 respondents of millennial generations in DKI Jakarta Province shows that the average value of responses about the questionnaires are in the lacking category. Most of the employees are inactive to do career planning, the employees tend to just follow the instructions in overcoming problems, and also reluctant to express an opinion when in or outside the forum.

In the presence of low proactive work behavior, then the factors that affect it need to be observed. According to Gulyani (2016) the aspect of protean career attitude is one of the factors that affect proactive work behavior. Research Hall in Gulyani and Bhatnagar (2017) current career paradigms depended on the individuals who undergo. This type of career is called protean career. The attitude of protean career is described as an attitude which someone, who manages his own career and understands the meaning of the success gained is internal or psychologic success, not external and also responsible for individual career decision making. Magdalena (2018) argued in it's development that the relationship between protean career attitude and proactive work behavior is also affected by the employee's passion for work. Forest et al (2012) defined passion for work as a strong individual inclination for his beloved job and the assumption that the work is a very important part from himself which an individual can invest his large amount of time and energy into the work.

According to Briscoe et al (2006) and also the research of De Vos and Segers (2013) other factors also affected proactive work behavior nowadays, one of them was career self management. Kossek et al (2006) defined career self management as a tendency of employees to 
collect information systematically and make problem solving planning and make decisions. Based on the phenomenon that occus to millennial employees related to the attitude of protean career, career self management, and passion for work to proactive work behavior to become the research background of the researcher to conduct research. The description of research from those variables will provide benefits to the institution management to consider the preparation of a career system that is adjusted to the condition of employees in DKI Jakarta Province.

\section{LITERATURE REVIEW}

\section{Millennial Generation}

According to Noe (2016) Y generation or millennials who were born between 1980-1999. Or at this time are in the age of 20-39 years old. According to the survey conducted by Manpower Group ("Millenials careers: 2020 vision", 2016), millennial generations will dominate one third of the workforce in the world in $2020.35 \%$ of the workers in the world will be dominated by millennial generations, the same percentage by $\mathrm{X}$ Generation, $24 \%$ of $\mathrm{Z}$ Generation and $6 \%$ of Baby Boomerss. Or at this time are in the age of 20-39 years old. According to Generation Y changing with the times (2011), the characteristics attached to the millennial generation are very affected by the changing social and economic environment. Those changes affect on the characteristics of millennial generation generally or in the work place, the characteristics that are so attached to millennial generations have different meaning about the success of a career, millennials defines success based on what they have learnt and the skills they have acquired, work life balance also becomes an important factor for millennials in a career.

\section{Proactive Work Behavior}

Tummers et al (2015) stated that the changes in the nature of work and organization occurred, causes the organization to be under pressure to adapt with changing circumstances. Therefore, proactive work behavior is considered very important in a decentralized workplace this time, which the competition is greater and the pressure continues to grow to innovate. According to Robbins (2009) who revealed that proactive work behavior was the employees who initiate to improve the situation or make new initiatives when other employees are passive in dealing with various situations that exist. Proactive employees tend to be able to see opportunities, dare to act, and persevere so that success to achieve significant goals.

According to Parker et al (2006) there were two dimensions included in it like implementation of ideas and proactive problem solving, first career initiative, career initiative is defined as employees who have high initiative to improve his own career without waiting to be facilitated by the company they work for. Besides that, career initiative also shows a number of strategies used by the employees who wants to advance their career goals. Second, personal initiative, personal initiative refers to when the employees have problems or difficulties to achieve their career goals, the employees will be active and fast trying to overcome the problems.

\section{Protean Career Attitude}

Grimland et al, (2012) occurred a shift between career path model which previously traditional became protean career. Current career paradigm is more dependent on the individuals who undergo. This type of career is usually called protean career. Protean career attitude is more active and determined by own self compared to passive traditional career. Volmer \& Spurk (2010) stated that the word protean was synonym from the word flexible, adaptive, and changeable. Hall and Mirvis (2014) argued that protean career was a formula or new orientation from career which the individual was more responsible and not the organization of the transformation of it is own career path.

Hall (2006:201) revealed that employees with protean career attitude had their own career choice. The need for self-fulfillment is an important part in his life, success criteria for himself is from within (psychological success), not criteria that are visible from the outside. In short, protean career is formed in an individual, not carried by the organization, and might be formed from time to time to fulfill individual needs. 
Then, Briscoe \& Hall (2006) does conceptualization to protean career by dividing into two dimensions. The first dimension are self directedness, self directed refer to the individual's ability to be more adaptive, self directed, and also refer to how far the employees manage their own careers systematically, the employees play an independent role without other people or organization intervention in managing their attitude towards work in order to achieve the success they want in their careers. Second, values driven is defined as the employee's attitude which align decisions that will be taken by them for their career with their own values and objectives, the individuals prioritize their personal values and make them as the parameter of a career success.

\section{Passion For Work}

Passion for work has an important role for employees, to facilitate or maintain the quality of work, because employees who have a passion tend to be interested in work based on their skills and desires. And can interact with leaders with a sense of comfort without fear and pressure. Forest et al (2012) passion for work is interpreted as a strong tendency of individuals to work that is loved by them and the assumption that the work is a very important part of themselves where an individual can invest a large amount of time and energy he has into the work. Meanwhile, according to Hasibuan (2009) passion for work is the enthusiasm or enthusiasm of employees in completing their work properly and discipline in achieving optimal work performance. Vallerand et al (2010) reveals the dualism model of passion for work that includes two dimensions, namely harmonious passion refers to an autonomous process which on its own volition completes work significantly without external factors such as pressure from the leadership, and others. Second, obsessive passion is characterized by pressure from outsiders or coercion to increase recognition from the work environment. This emphasis on obsessive passion can control people, who then feel they have to pursue activities in order to maintain self-esteem.

\section{Career Self Management}

According to Kossek et al. in Chiaburu, Baker and Pitariu (2006), career self management was defined as employee's tendency to collect information systematically and make problem solving planning as well as make decisions. Sturges et al (2002:733) revealed that career self management was done through information search about that person, networking activities, and receiving awards in order to success in his work. Noe (in Cline and Kisamore, 2008) stated that there was a dimension place of self management, such as Creating Career Opportunities was the employees explore unknown things in potential things and try to get new skills to add ability; Self Nomination is an employee's effort to emphasize the result and performance to achieve his career goals. Career Support which the employees try to get support from various parties to reach a clear level in the career he wants; Networking is developing network expansion with various forms of relationship for potential career changes.

$\mathrm{H}_{1}$ : There is a positive effect between protean career attitude and proactive work behavior;

$\mathrm{H}_{2}$ : There is a positive effect between protean career attitude and passion for work;

$\mathrm{H}_{3}$ : There is a positive effect between passion for work and proactive work behavior;

$\mathrm{H}_{4}$ : There is a positive effect between protean career attitude and career self management;

$\mathrm{H}_{5}$ : There is a positive effect between career self management and proactive work behavior;

$\mathrm{H}_{6}$ : Passion for Work mediates the effect between protean career attitude and proactive work behavior;

$\mathrm{H}_{7}$ : Career self management mediates the effect between protean career attitude and proactive work behavior. 


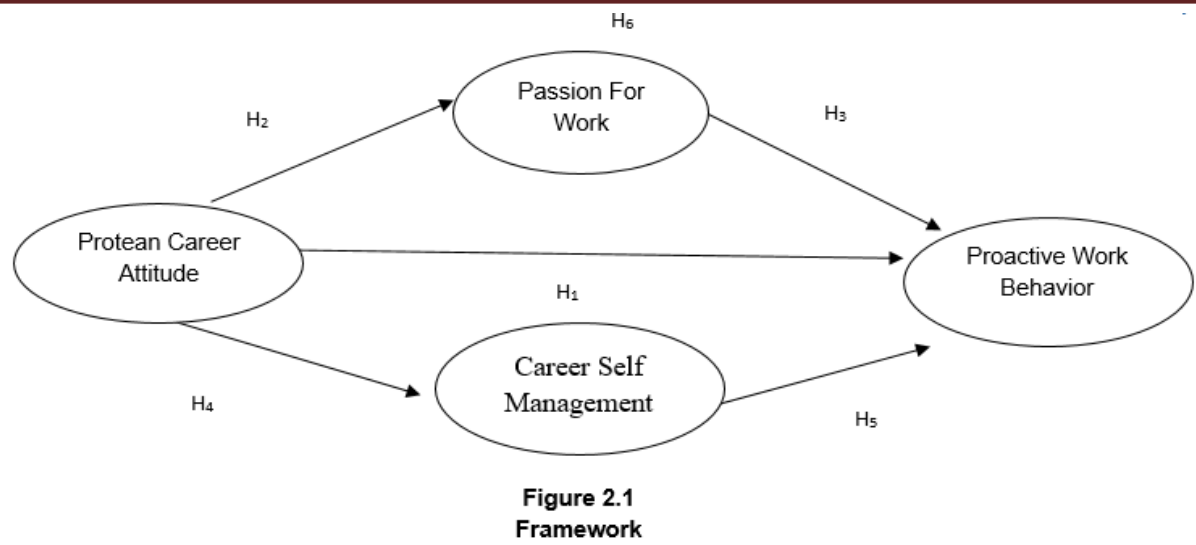

RESEARCH METHOD

The population of this research are government employees from millennial generations of DKI Jakarta Province. Which are based on Regional Personnel Agency with the total of 14.504 employees. The sampling used in this research is purposive sampling, which is sampling method is based on the criteria predefined. The sample criteria used in this research are government employees with the year of birth between 1980-1999 in DKI Jakarta Province, with functional position. In order to make the samples of this research able to represent the population, then the number of samples can be determined by using Umar (2009 :78) formula as follows.

$$
\mathrm{n}=\frac{N}{1+N e^{2}}
$$

Information :

$\mathrm{n} \quad=$ Total Sample

$\mathrm{N} \quad=$ Population Size

e $\quad=$ Percentage of leeway for inaccuracy $5 \%$

Based on that sampling technique, the sample below is obtained :

$$
\begin{gathered}
\mathrm{n}=\frac{14.504}{1+14.504(0,05)^{2}} \\
=389
\end{gathered}
$$

The method used in this research is quantitative method. The data collection is done by using questionnaires, the structured questionnaires are divided directly to the respondents to be filled. The data used later is processed by using Structural Equation Model (SEM). The data is processed with AMOS 22 software to test reliability, validity, structural model data estimation in testing hypothesis. This research is also conducted by sobel test, sobel test aims to know the effect of mediation variable which are passion for work and career self management.

\section{RESULT AND DISCUSSION}

\section{The Influence of Protean Career Attitude on Proactive Work Behavior}

Protean Career Attitude has a significant positive effect on the Proactive Work Behavior of Millennial Employees in DKI Jakarta Province. This is shown by probability value of $0,000(0 \%)$ which is under alpha of $5 \%(0,05)$. Therefore, hypothesis $\mathrm{H}_{1}$ is proved in this analysis. The results of this study support previous research conducted by Magdalena (2018), Gulyani and Bhatnagar (2017), Baruch (2015), Rahim (2015). 


\section{The Influence of Protean Career Attitude on Passion For Work}

Protean Career Attitude has a significant positive effect on Passion For Work of Millennial Employees in DKI Jakarta Province. This is shown from it is significance of 0,002 which is under alpha of $5 \%(0,05)$. Therefore, hypothesis $\mathrm{H}_{2}$ is proved in this analysis. This is in line with research conducted by Ramadhan (2018), Gulyani and Bhatnagar (2017), Issanti (2018) which proves that the protean career attitude influences passion for work.

\section{The Influence of Passion For Work effect on Proactive Work Behavior}

Passion For Work has a significant positive effect on Proactive Work Behavior. This is shown from it's significance value of 0,004 which is under alpha of $5 \%(0,05)$. Therefore, hypothesis $\mathrm{H}_{3}$ is proved in this analysis. These results are in line with research conducted by Ramadhan (2018), Magdalena (2018), Issanti (2018), Gulyani and Bhatnagar (2017) where passion for work influences proactive work behavior.

\section{The Influence of Protean Career Attitude on Career Self Management}

Protean Career Attitude has a significant positive effect on Career Self Management. This is shown by probability value of 0,008 which is under alpha of $5 \%(0,05)$. Therefore, hypothesis $\mathrm{H}_{4}$ is proved in this analysis. This result is in line with research conducted by Ramadan (2018), Soens and De Vos (2008), Chiaburu et al (2006) which states that the protean career attitude has a positive effect on career self management.

\section{The Influence of Career Self Management on Proactive Work Behavior}

Career Self Management has a significant positive effect on Proactive Work Behavior. This is shown by probability value of $0,000(0 \%)$ which is under alpha of $5 \%(0,05)$. Therefore, hypothesis $\mathrm{H}_{5}$ is proved in this analysis. This result is supported by research conducted by Chiaburu et al (2006), De Vos and Segers (2013) which states that career self management has a positive effect on proactive work behavior.

\section{The Influence of Protean Career Attitude on Proactive Work Behavior from Passion For Work}

Protean Career Attitude has a significant effect on proactive work behavior from passion for work. Based on the test result with three methods such as sobel test, aroian test, and goodmen test, it shows that T Statistic is greater than T value of Table 1,960 so that it can be said that there is an effect of protean career attitude to proactive work behavior from passion for work. These results are in line with research conducted by Ramadhan (2018), Issanti (2018), Gulyani and Bhatnagar (2017). So it can be concluded that the protean career attitude influences proactive work behavior through passion for work.

\section{The Influence of Protean Career Attitude on Proactive Work Behavior from Career Self Management}

Protean career attitude has a significant effect on proactive work behavior from career self management. Based on the test result with three methods such as sobel test, aroian test, and goodmen test, it shows that T Statistic is greater than $\mathrm{T}$ value of Table 1,960 so that it can be said that there is an effect of protean career attitude on proactive work behavior from career self management. This result is in line with research conducted by Ramadan (2019). So it can be concluded that career self management mediates the relationship between protean career attitudes and proactive work behavior. 


\section{CONCLUSION AND RECOMMENDATION}

\section{Conclusion}

From the results of this research, it can be concluded that 1) Behavior in Millennial Employees of the DKI Jakarta Provincial Government, 2) Protean career attitude has a positive and significant effect on passion for work for Millennial Employees of the DKI Jakarta Provincial Government, 3) Passion for work has a positive and significant effect on proactive work behavior of Millennial Employees in the DKI Jakarta Provincial Government, 4) Protean career attitude has a positive and significant effect on career self management on Millennial Employees of the DKI Jakarta Provincial Government, 5) Career self management has a positive and significant effect on proactive work behavior in Millennial Employees of the DKI Jakarta Provincial Government, 6) Protean career attitudes have a significant effect on proactive work behavior through passion for work for Millennial Employees of the DKI Jakarta Provincial Government, 7) Protean career attitude has a significant effect on proactive work behavior through career self management in Millennial Employees of the DKI Jakarta Provincial Government.

\section{Recommendation}

From the conclusions obtained then it can be known that there is an effect of protean career attitude, proactive work behavior, passion for work, career self management to the Millennial Employees of DKI Jakarta Province, these efforts should be made in order to increase proactive work behavior:

1. Operational for Institutional Interests

a. Institution needs to identify modern career perspectives, especially protean career attitude to millennial generations, so that the institution can provide appropriate career management. This will have an effect to the millennial generation employees' proactive work behavior in a career. In this thing, it is important for the institution to give emphasis that career success or failure is personal responsibility, and increase the employees' trust to be able to be proactive and dare to voice their ideas or opinions.

b. Institution needs to build employees' awareness that the responsibility of a career success or failure is based on the employees themselves, this will increase independence of the employees' career.

c. Company is expected to increase the employees' spirit at work, by giving enough salary, provide adequate facilities, give reward as well as opportunities to be able to develop their career.

d. Company needs to support and facilitate the employees to get information needed as wide as possible in order to help them to develop their career.

2. Academic

Based on the research result and discussion, then the researcher gives some advices as follows:

a. In this research, proactive work behavior is only reviewed from protean career attitude, passion for work, career self management. For future researchers, it is advice to add some other variables so that it can be known that proactive work behavior is also affected by other factors which are not covered in this research, like human resource practices, work attachment.

b. Further researches should be able to use other research methods except questionnaires, like interview method, so that two way communication can be intertwined with the respondents.

c. Further researches are expected to be conducted in other places, like private companies, and for all generations of the workforce. 


\section{REFERENCES}

Briscoe, J. P., Hall, D. T., \& Frautschy DeMuth, R. L. (2006). Protean and boundaryless careers: An empirical exploration. Journal of Vocational Behavior, 69(1), 30-47. https://doi.org/10.1016/J.JVB.2005.09.003

Chiaburu, D. S., Baker, V. L., \& Pitariu, A. H. (2006). Beyond being proactive: what (else) matters for career self-management behaviors? Career Development International, 11(7), 619-632.

Crant, J. M. (2000). Proactive behavior in organizations. Journal of management, 26(3),435-462. Educated Limited.

Kossek, E. E. (1998). Career self-management: a quasi-experimental assessment of the effects of a training intervention. Personal Psychology, 51, 935-962

Forest, Jacques., Lavigne, Genevieve., Crevier-Braud, Laurence. (2012). Passionat work and burnout: A two-study test of the mediating role of flow experiences. European Journal Of Work and Organizational Psychology. 21:4, 518-546

Grimland, S., Vigoda-Gadot, E., \& Baruch, Y. (2012). Career attitudes and success of managers: the impact of chance event, protean, and traditional careers. The International Journal of Human Resource Management, 23(6), 1074-1094

Gulyani, G., \& Bhatnagar, J. (2017). Mediator analysis of passion for work in Indian millennials. Career Development International, 22(1), 50-69

Lynch, A. J. (2008). ROI on generation Y employees. Bottom Line Conversations, 28

Maden, C. 2015. Linking High Involvement Human Resources Practices to Employee Proactivity.Personal Review, 44 (5),720 - 738.

Magdalena, S. L. (2018). Pengaruh Protean Career Attitude Terhadap Proactive Work Behavior Dengan Mediasi Passion For Work Pada Generasi Milenials Di Dki Jakarta. Prosiding Working Papers Series In Management, 10(2).

Parker, S. K., \& Collins, C. G. (2010). Taking stock: Integrating and differentiating multiple proactive behaviors. Journal of Management, 36(3), 633-662.

Robbins, Stephen P. \& Timothy A. Judge. 2009.Organizational Behavior. 13 ThreeEdition, USA: Pearson International Edition, Prentice-Hall.

Soens, N., \& De Vos, A. (2008). Protean attitude and career success: The mediating role of selfmanagement. Journal of Vocational Behavior, 73(3), 449-456.

Sturges, J., Guest, D., Conway, N., \& Mackenzie D. K. (2002). A longitudinal study of the relationship between career management and organizational commitment among graduates in the first ten years at work. Journal of Organizational Behavior, 23(6), 731-748.

Twenge, J. M., Ciarocco, N. J., Baumeister, R. F., \& Bartels, J. M. (2007). Social exclusion decrease prosocial behavior. Journal of personality and social psychology 2007, Vol. 92, No. 1, 56-66.The American Psychological Association.

Vallerand, R. J., Paquet, Y., Philippe, F. L., \& Charest, J. (2010). On the role of passion burnout: a process model. Journal of Personality, 78(1), 289-312.

Volmer, J., \& Spurk, D. (2011). Protean and boundaryless career attitudes:

Relationships with subjective and objective career success. Zeitschrift für ArbeitsmarktForschung, 43(3), 207-218.

Vos, A., Clippeleer, I., \& Dewilde, T. (2009). Proactive career behaviours and career success during the early career. Journal of Occupational and Organizational Psychology, 82(4), 761-777.

https://news.gallup.com/opinion/chairman/191426/millennials-live-work.aspx, diakses pada 20 Juni 2019. 